Indonesian Journal of Theology 4/1 (July 2016): 45-77.

\title{
Narasi Para Korban sebagai Basis Konstruksi Identitas Sosial Kristen yang Terbuka
}

\section{Astrid Bonik Lusi}

\begin{abstract}
Narratives of the violence victims can contribute to an open Christian social identity. This article contains violence narratives of women in East Timor and narratives about First Peter community. There are two reasons behind the selection of those narratives. First, both narratives are violence narratives from the victims' perspective and trauma narratives. Second, those different narratives show the link between narratives in everyday life and narratives that come from the Bible. The purpose of the selection of these narratives is to give a deep understanding about violence and trauma and their contribution to the construction of an open Christian social identity.
\end{abstract}

Keywords: Women in East Timor, First Peter Community, Violence Narratives, Trauma Narratives, and Open Christian Social Identity

\begin{abstract}
Abstrak
Narasi para korban kekerasan mampu memberi sumbangsih bagi identitas sosial Kristen yang terbuka. Tulisan ini memuat narasi kekerasan kaum perempuan Timor Timur $^{1}$ dan narasi tentang komunitas 1 Petrus. Ada dua alasan yang melatarbelakangi pemilihan narasi-narasi tersebut. Pertama, kedua narasi merupakan narasi kekerasan dari perspektif para korban sekaligus narasi trauma. Kedua, narasi-narasi yang berbeda tersebut memperlihatkan pertautan antara narasi dalam kehidupan sehari-hari dan narasi yang bersumber dari teks Alkitab. Tujuan pemilihan kedua narasi tersebut adalah memberikan
\end{abstract}

${ }^{1}$ Istilah Timor Timur lebih lazim digunakan sebelum kemerdekaan Timor Timur pada 20 Mei 2002. Sejak kemerdekaan Timor Timur, istilah Timor Timur diganti menjadi Democratic Republic of Timor Leste (Portugis) atau Timor Lorosa'e. Dalam bahasa Tetun, Timor Lorosa'e berarti Timor of the rising sun (Rimmer 2010, 163). Dalam tulisan ini, saya memilih untuk menggunakan istilah Timor Timur karena narasi perempuan yang saya kemukakan adalah narasi perempuan yang menderita karena pendudukan Indonesia sebelum kemerdekaan Timor Timur hingga Timor Timur merdeka. 
pemahaman yang mendalam mengenai kekerasan dan trauma, serta berkontribusi untuk mengkonstruksi suatu identitas sosial Kristen yang terbuka.

Kata-Kata Kunci: kaum perempuan Timor Timur, komunitas 1 Petrus, narasi kekerasan, narasi traumatis, identitas sosial Kristen terbuka.

\section{Pendahuluan: \\ Narasi Kekerasan Kaum Perempuan Timor Timur dan Komunitas 1 Petrus}

Berbicara tentang siapa kita adalah berbicara tentang suatu narasi, narasi yang menyatakan asal dan tujuan yang hendak kita tuju. Narasi merupakan aspek penting dalam bangunan suatu komunitas. ${ }^{2}$ Narasi adalah cerita-cerita yang membentuk dan meneruskan memorimemori ${ }^{3}$ dari individu atau komunitas. Narasi tidak dapat dilepaskan dari memori. Memori adalah dasar dari identitas. ${ }^{4}$ Tanpa memori kita tidak dapat mengkonstruksi suatu bangunan baru dalam berpikir dan bertindak. Melalui memori, kita mampu untuk mengungkapkan narasinarasi yang membentuk bahkan menggugah kesadaran kita.

Dalam wacana misi Kristen, narasi tidak hanya bersumber dari teks Alkitab. Nancy T. Ammerman mengatakan bahwa narasi religiositas bersumber dalam kehidupan sehari-hari. Narasi-narasi personal maupun komunitas menjadi sesuatu yang sakral, karena ia berfungsi di tengah masyarakat. Narasi mengungkapkan sekaligus membentuk identitas seseorang ataupun suatu komunitas. Narasi bekerja di dalam ruang privat dan ruang publik. ${ }^{5}$ Narasi dapat menyediakan beragam jawaban terhadap suatu pertanyaan atau situasi yang sulit, ${ }^{6}$ karena ia memberi ruang untuk berimajinasi dan mengkonstruksi suatu pemikiran.

2 Clemens Sedmak, Doing Local Theology: A Guide for Artisans of a New Humanity, Faith and Cultures Series (Maryknoll, N.Y.: Orbis Books, 2002), 155.

${ }^{3}$ Nancy Tatom Ammerman, Studying Congregations: A New Handbook. (Nashville: Abingdon Press, 1998), 33.

${ }^{4}$ Ibid., 28.

${ }^{5}$ Nancy Atom Ammerman, Sacred Stories, Spiritual Tribes: Finding Religion in Everyday Life (New York: Oxford University Press, 2014), 8-9.

${ }^{6}$ Sedmak, Doing Local Theology, 155. 


\section{Narasi Kekerasan Kaum Perempuan Timor Timur}

Dalam kehidupan masyarakat Timor Timur, perempuan Timor Timur adalah warga kelas dua. Mereka berada di bawah kekuasaan lakilaki. Mereka tidak menerima peluang pendidikan atau pekerjaan yang sama dengan laki-laki. Pada pihak lain, kekerasan rumah tangga terhadap perempuan Timor Timur merajalela karena perempuan Timor Timur adalah budak di rumah mereka sendiri. Perempuan Timor Timur dibeli dan dijual seperti komoditas di bawah tradisi belis atau mas kawin. Situasi tersebut sulit untuk diubah. Sister Maria de Lourdes Martins Cruz berkata, "Men leaders still unwilling to accept East Timorese women as equals." 7

Kekerasan yang dialami oleh kaum perempuan Timor Timur tidak terlepas dari sejarah kekerasan di Timor Timur. Sejak Portugis menjajah Timor Timur, kepentingan-kepentingan ekonomi dan politik para penguasa hampir selalu dijalankan secara koersif. ${ }^{8}$ Ketika berada dalam situasi tersebut, masyarakat Timor Timur tidak saja kehilangan nyawa, mereka bahkan terbiasa untuk mengadaptasi pola-pola kekerasan yang terjadi. Rangkaian kekerasan pun membentuk karakter mereka.

Menurut catatan sejarah dan statistik, pendudukan Indonesia di Timor Timur pada tahun 1975-1999 adalah tindakan penindasan dan kekejaman terburuk yang pernah dialami oleh masyarakat Timor Timur. ${ }^{10}$ Ancaman komunis dan kekhawatiran bangkitnya PKI menjadi pembenaran bagi pemerintah Indonesia pada lingkup dalam negeri dan internasional untuk memasukkan Timor Timur ke dalam Indonesia. ${ }^{11}$ Bagi pemerintah Indonesia, ancaman tersebut adalah ancaman bagi keamanan nasional Indonesia. Australia menjadi negara yang mendukung keputusan Soeharto atau pemerintah Indonesia pada masa itu. ${ }^{12}$

Ada tiga hal yang perlu untuk diperhatikan mengenai pendudukan Indonesia di Timor Timur. Pertama, kedatangan militer

\footnotetext{
${ }^{7}$ Susan Harris Rimmer, Gender and Transitional Justice: The Women of East

Timor, Routledge Contemporary Southeast Asia Series (London; New York:

Routledge, 2010), 16.

${ }^{8}$ Karen Campbell-Nelson, dkk, Perempuan Dibawa/ h Laki-Laki yang Kalah: Kekerasan terhadap Perempuan Timor Timur dalam Kamp Pengungsian di Timor Barat (Kupang: JKPIT \& PIKUL, 2001), 13.

${ }^{9}$ Ibid., 14.

${ }^{10}$ Ibid.

${ }^{11}$ Helene van Klinken, Anak-Anak Tim-Tim di Indonesia: Sebuah Cermin Masa Kelam (Jakarta: KPG (Kepustakaan Populer Gramedia), 2014), 35-38.

12 Pat Walsh, Di Tempat Kejadian Perkara: Tulisan, Refleksi, dan Puisi tentang Timor Leste, 1999-2010 (Jakarta: KPG (Kepustakaan Populer Gramedia), 2012), 2.
} 
Indonesia secara besar-besaran ke Timor Timur dari laut dan udara pada 7 Desember 1975 merupakan sebuah penyerbuan yang diikuti dengan proses pengambilan wilayah atau aneksasi. Aneksasi Timor Timur coba disahkan oleh UU NO. 7/1976 dan TAP MPR No. VI/MPR/1978. Saat aneksasi tersebut berlangsung, sesungguhnya Timor Timur sedang menjalani proses menuju masyarakat yang merdeka dari status masyarakat jajahan Portugis. Aneksasi adalah tindakan yang melanggar hak asasi masyarakat Timor Timur untuk menentukan nasib sendiri. Pelaksanaan jajak pendapat di Timor Timur pada bulan Agustus 1999 adalah proses penentuan nasib sendiri yang seharusnya terselesaikan 24 tahun yang lalu. ${ }^{13}$

Kedua, dunia Internasional melalui PBB tidak pernah mengakui apa yang disebut Indonesia sebagai integrasi. PBB menolak aneksasi Indonesia atas Timor Timur dan menyerukan agar hak penentuan nasib sendiri oleh masyarakat Timor Timur harus dihormati. Pada pihak lain, Indonesia tidak menggubris seruan dari PBB. ${ }^{14}$

Ketiga, dengan melakukan penyerbuan atas Timor Timur, pemerintah dan militer Indonesia tidak hanya melanggar hukum dan perjanjian Internasional, tetapi juga mengingkari prinsip dasar pendirian negara Indonesia. Prinsip tersebut termuat dalam pernyataan Pembukaan UUD 1945 yang berbunyi, "Bahwa kemerdekaan adalah hak segala bangsa dan penjajahan di atas dunia harus dihapuskan, karena tidak sesuai dengan perikemanusiaan dan perikeadilan." 15 Keserakahan yang tiada habis untuk mengeruk ekonomi minyak dan gas bumi menjadi faktor utama yang melatarbelakangi semangat penyerbuan atas Timor Timur. Keserakahan tersebut juga mempererat persahabatan Australia dan Soeharto. ${ }^{16}$

Kepentingan politik-ekonomi yang rumit melanggengkan kekerasan yang dialami oleh masyarakat Timor Timur, terkhususnya kaum perempuan. Pemerkosaan, penyiksaan, dan tindakan lain yang tidak manusiawi adalah harga perang yang harus ditanggung oleh perempuan dalam situasi konflik. ${ }^{17}$

Cecelia Soares adalah seorang perempuan Timor Timur. Pada tanggal 7 Desember 1975, usia pernikahannya berumur satu tahun. Tiga bulan sebelum tanggal tersebut, yakni September 1975, Soares melahirkan seorang bayi perempuan. Kebahagiaan hadir dalam

\footnotetext{
13 Campbell-Nelson, Perempuan Dibawa/h Laki-Laki yang Kalah, 14.

14 Ibid., 15.

15 Ibid.

16 Ibid., 16.

17 Ibid., 99.
} 
kehidupan Soares, namun situasi yang membahagiakan itu lenyap ketika tentara Indonesia hadir di Timor Timur. ${ }^{18}$

I used to live near the Dili port and on that day I saw planes dropping Indonesian paratroopers. And that was the day my life was shattered forever... The next thing I knew there were battleships firing shells. It was frightening. I ran home, grabbed my baby, and then just ran to the hills. I tried looking for my husband, but he was nowhere to be seen. My daughter and I lived with the Falintil ${ }^{19}$ resistance in the hills for four years, until we were captured by Indonesian troops and sent to prison on Atauro Island, 22 kilometers north of Dili. It was hell there. There wasn't enough food, we were tortured, and my girl who was now about four died of hunger. I once tried to commit suicide but I was saved by a priest who told me that Timor would be free someday and all the suffering would end. ${ }^{20}$

Saat tentara Indonesia mendarat di Timor Timur, mereka meminta perempuan atau mengejar-ngejar perempuan yang dianggap menarik. ${ }^{21}$ Akibatnya, banyak perempuan yang menggunting pendek rambut mereka, tidak menyisir rambut, memakai kaos dan celana pendek, memakai pakaian yang kotor, berjalan dengan telanjang kaki, serta membebat payudara mereka agar terlihat rata. ${ }^{22}$ Semua tindakan itu dilakukan karena kaum perempuan Timor Timur takut terhadap kasus pemerkosaan brutal yang terjadi pada saat itu.

Kasus pemerkosaan brutal diceritakan secara lugas oleh Dom Martinho da Costa Lopes. Ia adalah pemimpin politik dan keagamaan di Timor Timur. Berikut cerita Dom Martinho, sebelum ia ditarik oleh Vatikan karena kritiknya yang sangat keras terhadap penjajah Indonesia:

Banyak orang berdatangan pada saya untuk berbicara secara rahasia untuk menjernihkan pikiran mereka dari apa yang terpaksa mereka lihat atau lakukan. Meski waktu pengakuan dosa sudah selesai, orang masih berdatangan, mengetuk pintu

\footnotetext{
18 Rimmer, Gender and Transitional Justice: The Women of East Timor, 50.

${ }^{19}$ Falintil adalah singkatan bahasa Portugis dari Forças Armadas da

Libertação Nacional de Timor-Leste. Dalam bahasa Indonesia, istilah tersebut berarti Angkatan Bersenjata Pembebasan Nasional Timor Timur (Nevins 2008, xiv). ${ }^{20}$ Ibid.

21 Negara dan Kekerasan terhadap Perempuan, ed. George J. Aditjondro, Kekerasan Negara terhadap Perempuan di Timor Timur (Jakarta: Yayasan Jurnal Perempuan (YJP), 2000), 161.

22 Ibid., 161-62.
} 
saya dengan lembut untuk bicara dengan saya karena mereka merasa sangat bersalah dipaksa oleh prajurit untuk melakukan hal yang mereka tahu itu salah... Mereka datang untuk membicarakannya, juga perempuan, bahkan gadis-gadis... Seorang di antara gadis-gadis itu dimasukkan ke dalam sebuah tangki air bersama seorang laki-laki Timor, dan para prajurit itu memaksa mereka untuk melakukan hubungan seks. Mereka berada di hadapan para prajurit di dalam sebuah tangki penuh air! Orang-orang Timor ini tidak saling mengenal satu sama lain. Mereka tidak dapat melakukan hal itu tentu saja, mereka saling membelakangi karena mereka malu. Kejadian seperti itu membuat saya berpikir mereka itu gila, para prajurit-prajurit itu. Mereka sepertinya tak punya moral, tak punya peri kemanusiaan. Satu hal yang menjadi kebiasaan favorit mereka adalah memperkosa istri di hadapan suaminya, bahkan terkadang juga di hadapan anak-anaknya. Bagi orang Timor yang lebih buruk daripada penderitaan fisik adalah penderitaan moral yang mereka alami, dipermalukan, dan harga diri mereka dirampas. Saya berkata pada prajurit-prajurit Indonesia, "Tidakkah kalian mempunyai ibu, saudara perempuan, tahukah kalian bagaimana rasanya menjadi manusia?"23

Narasi di atas adalah salah satu narasi tentang pelanggaran hak asasi manusia yang dilakukan oleh tentara Indonesia terhadap perempuan. Kasus tersebut tidak pernah diusut secara tuntas.

Dalam operasi militer berskala besar, setelah invasi awal pada tahun 1975, ribuan penduduk sipil Timor Timur, termasuk laki-laki, perempuan, dan anak-anak yang tidak bersenjata dan tidak mampu melindungi diri mereka sendiri, menjadi sasaran pembunuhan oleh tentara Indonesia. ${ }^{24}$ Tentara Indonesia secara rutin menyiksa dan membunuh penduduk sipil dan tahanan perang yang tertangkap, termasuk wanita hamil dan anak-anak.

The exact number of Timorese deaths at the hands of Indonesian military is not definitively known, with estimates ranging from 120,000 to 230,000. On 12 November 12 1979, Indonesia's foreign minister, Mochtar Kusumaatmadja, estimated that 120,000 people had died in East Timor since

\footnotetext{
23 Ibid., 162-63.
}

${ }^{24}$ Comissão de Acolhimento Verdade e Reconciliação Timor Leste (CAVR), Chega! The Report of the Commission for Reception, Truth, and Reconciliation Timor-Leste Executive Summary (Timor Leste: Comissão de Acolhimento Verdade e Reconciliação Timor Leste (CAVR), 2005), 112. 
1975. Amnesty International estimates that 200,000 died from military action, starvation or disease from 1975-99. A genocide expert Ben Kiernan has noted that the deaths must also be seen in the context of the total original population base of just 700,000 people. The Final Report entitled Chega! ('Enough' in Portuguese) by Timor's Commission for Reception, Truth and Reconciliation (CAVR) released in 2006 says that an upper estimate of 183,000 died as a result of both killings and deaths due to privation. CAVR's estimate of the minimum total number of conflict related deaths is 102,800 (plus or minus 12,000). The report finds that 18,600 non-combatant East Timorese were killed or disappeared and at least 84,000 more died as a direct result of displacement policies during Indonesia's occupation. $^{25}$

Penganiayaan yang terjadi di Timor Timur berdampak pada pengungsian warga sipil Timor Timur dalam jumlah yang sangat besar ke wilayah Timor Barat. Akibatnya, wilayah Timor Barat menjadi wilayah yang sangat rentan terhadap konflik. ${ }^{26}$

Dalam kamp pengungsian, kaum perempuan berada dalam posisi yang tidak menguntungkan. Perempuan berada pada posisi dibawa/di bawah. Mereka bukan saja dibawa dari Timor Timur ke Timor Barat, tetapi juga berada dalam posisi di bawah atau bergantung secara ekonomis, psikologis, dan sosio-budaya terhadap laki-laki. ${ }^{27}$ Laki-laki yang dimaksud ialah mereka yang pro-otonomi atau prointegrasi, mereka yang kalah dalam pertarungan jajak pendapat 1999.

Kerentanan kaum perempuan dalam kamp pengungsian dapat terlihat dari banyaknya kasus pemerkosaan yang terjadi dalam keluarga, pemerkosaan terhadap pekerja seks lokal, pemerkosaan massal, dan percobaan pemerkosaan. Banyak perempuan yang setiap malam diperkosa oleh laki-laki yang tidak dikenal pada tanggal 15, 16, dan 17 September $1999 .^{28}$

Seorang perempuan berumur 21 tahun dari kamp Halilulik bernama Maria (nama samaran) mengalami tindak pemerkosaan ketika hendak ke WC yang dilakukan oleh seorang laki-laki yang tidak dikenal. Menurut pengakuan korban, pelaku tersebut berciri-ciri tinggi, berkulit hitam, berambut keriting, berkumis, mengenakan kaus tentara, dan

\footnotetext{
25 Ibid., 51.

26 Campbell-Nelson, Perempuan Dibawa/ h Laki-Laki yang Kalah, v-vii.

27 Ibid., 3.

28 Ibid., 95.
} 
menggunakan sepatu loreng. Peristiwa itu terjadi kira-kira pukul 21.00 malam (korban lupa waktunya) saat korban ke luar dari kamp hendak ke WC yang jaraknya kira-kira $10 \mathrm{~m}$ di bagian belakang kamp. Setelah ke luar dari WC, tiba-tiba dari arah belakang korban, datang seorang yang langsung menyumbat mulut korban dengan kedua tangannya. Korban tidak bisa berteriak, tapi sempat berontak, tapi tidak bisa menghindar dari cengkeraman tadi. Dalam keadaan panik korban diancam dengan pisau untuk tidak berteriak. Korban lalu digiring ke kebun jagung yang jaraknya kira-kira 20 meter dari WC. Setiba di kebun jagung, korban, yang masih dalam keadaan takut, dipaksa untuk melucuti pakaiannya. Korban dengan sisa kekuatannya masih sempat mengadakan perlawanan untuk tidak melepaskan pakaiannya, dan pada saat itu korban ditampar dan akibatnya korban tidak berdaya dan pingsan. Beberapa saat kemudian korban sadarkan diri, tapi ia dalam keadaan tidak berpakaian dan ia merasa sakit di bagian selangkangannya. Dengan sisa tenaga yang ada padanya, korban berusaha mengenakan pakaian dan berjalan tertatihtatih menuju kamp. Tiba di sana korban jatuh, lalu menangis. Kemudian korban diangkat oleh beberapa orang pengungsi untuk dibaringkan di tempat korban tinggal. Melihat kondisi anaknya, ibu korban memanggil petugas kesehatan terdekat setelah ditangani oleh tim medis barulah diketahui bahwa korban baru saja diperkosa. ${ }^{29}$

\section{Narasi Kekerasan Komunitas 1 Petrus}

Surat 1 Petrus surat ditulis pada akhir abad I ZB atau $70-100$ ZB. ${ }^{30}$ Penulis teks 1 Petrus dalam 1 Petrus 1:1 menyatakan bahwa surat 1 Petrus merupakan surat yang ditujukan kepada lima provinsi Roma yang terletak di Asia Kecil. Kelima provinsi tersebut ialah Pontus, Galatia, Kapadokia, Asia, dan Bitinia. ${ }^{31}$ John H. Elliott mengatakan bahwa para penerima surat, komunitas 1 Petrus adalah pa,roikoj dan

\footnotetext{
29 Ibid., 93.

${ }^{30}$ Norman Perrin, Dennis C. Duling, and Robert L. Ferm, The New Testament, an Introduction: Proclamation and Parenesis, Myth and History, 2nd ed. (New York: Harcourt Brace Jovanovich, 1982), 377. Bandingkan dengan Perjanjian Baru: Sejarah, Pengantar, dan Pokok-Pokok Teologisnya (Hakh 2010, 330).

${ }^{31}$ John Hall Elliott, A Home for the Homeless: A Sociological Exegesis of 1 Peter, Its Situation and Strategy (United States of America: Fortress Press, 1981), 59. Bandingkan dengan Persecution in 1 Peter: Differentiating and Contextualizing Early Christian Suffering (Williams 2012, 63).
} 
parepi,dhmoj (1 Ptr. 1:1; 2:11). ${ }^{32}$ Pa,roikoj menunjuk kepada penduduk asing dengan keterbatasan hak dan status, sedangkan parepi,dhmoj menunjuk kepada para pengembara, pengunjung sementara yang tidak memiliki kesempatan untuk mempunyai tempat tinggal yang tetap. ${ }^{33}$ Melalui status pa,roikoj dan parepi,dhmoj, Elliott menyatakan bahwa permasalahan yang terjadi terhadap jemaat Kristen di Asia Kecil telah ada bahkan sebelum mereka menjadi Kristen. ${ }^{34}$ Status sebagai yang asing dan tak dikenal membatasi komunitas 1 Petrus dalam segala hal.

Pada pihak lain, Travis B. Williams berpendapat bahwa komunitas 1 Petrus merupakan Kristen-Non Yahudi karena permasalahan yang dialami oleh para penerima surat disebabkan oleh pertobatan mereka kepada iman Kristen. ${ }^{35}$ Williams menunjuk pada teks 1 Petrus 2:20; 3:14,16; 4:3-4 dan mengemukakan bahwa setiap kali penulis surat menggambarkan penyebab dari penderitaan komunitas 1 Petrus, ia menunjuk pada keterlibatan komunitas 1 Petrus dalam aktivitas-aktivitas Kristen. ${ }^{36}$

Pandangan Elliott dan Williams dapat saling melengkapi. Dalam 1 Petrus 1:1; 2:10 penulis surat menggunakan istilah pa,roikoj dan parepi,dhmoj untuk menyatakan status dari komunitas 1 Petrus. Penulis surat memang tidak menekankan penderitaan para penerima surat sebelum menjadi Kristen, namun hal itu tidak berarti ketiadaan penderitaan. Status sebagai yang asing dan tak dikenal memungkinkan penerima surat mengalami penderitaan sebelum menjadi Kristen. Namun, 1 Petrus menekankan tentang penderitaan yang dialami komunitas 1 Petrus sebagai penganut kepercayaan Kristen.

Williams mengatakan bahwa komunitas 1 Petrus memiliki keberagaman latar belakang ekonomi. Jumlah anggota komunitas yang kaya (1 Ptr. 3:3-4) sedikit, karena mayoritas anggota komunitas berada dalam situasi keuangan yang tidak stabil dan sulit. ${ }^{37}$ Sebagian besar komunitas 1 Petrus terdiri dari para pelayan dalam rumah tangga, oivke, tai. ${ }^{38}$

Ada beberapa bentuk kekerasan yang terjadi pada komunitas 1 Petrus. Pertama, kekerasan verbal. Anggota komunitas menjadi korban kekerasan verbal dari orang-orang yang tidak percaya. Mereka difitnah sebagai penjahat (1 Ptr. 2:12) dan dihina karena nama Kristus

\footnotetext{
32 Ibid., 23.

33 Ibid., 25, 30.

34 Ibid., 42-43.

35 Williams, Persecution in 1 Peter, 95.

36 Ibid., 102.

37 Ibid., 128.

38 Elliott, A Home for the Homeless, 69.
} 
(1 Ptr. 4:14). ${ }^{39}$ Dalam rumah tangga, para isteri difitnah oleh suaminya yang tidak percaya, dikucilkan tanpa proteksi dan jaminan ekonomi. ${ }^{40}$

Tetangga-tetangga dari komunitas 1 Petrus mengedarkan kabar buruk tentang mereka. Bahkan pada masa itu terdapat sketsa Yesus berkepala keledai yang tergantung pada salib. ${ }^{41}$ Pengabaian, kecurigaan, difitnah, dan diabaikan menghasilkan penderitaan, ketakutan, dan dukacita menjadi bagian dari Kekristenan. Anggota komunitas diberanikan untuk mendiamkan pengabaian orang-orang -orang bodoh dengan melakukan kebaikan (1 Ptr. 2:15). Mereka dinasihati untuk membalas kekerasan dengan cara memberkati (1 Ptr. 3:9). ${ }^{42}$

Kedua, kekerasan fisik. 1 Petrus 2:18 menjelaskan mengenai nasihat kepada oivke,tai untuk tunduk dengan penuh ketakutan kepada sang tuan, bukan saja kepada yang baik dan peramah, tetapi juga kepada yang bengis. Williams menyatakan bahwa penulis surat menguatkan mereka untuk bertahan, menahan penderitaan dengan melakukan yang baik, karena melalui itulah mereka mendapatkan keuntungan dari Allah. Tindakan penulis tersebut mengasumsikan bahwa jemaat di Asia Kecil menjadi subjek dari kekerasan tuan-tuan yang tidak dipercaya. ${ }^{43}$

Dalam dunia sosial komunitas 1 Petrus, seorang majikan memiliki hak istimewa untuk melakukan kekerasan tanpa batas kepada para budaknya. Para budak terkhusunya budak perempuan mengalami penderitaan yang luar biasa. ${ }^{44}$ Banyak yang mengalami kekerasan seksual, dicambuk, dicap, bahkan dimutilasi. Keadaan semakin kacau ketika budak memeluk agama Kristen, karena majikan menginginkan budak mengikuti agama yang dianutnya. ${ }^{45}$

Ketiga, tindakan-tindakan yang sah secara hukum. Komunitas 1 Petrus diklasifikasi sebagai seorang kriminal dengan tuduhan memiliki kepribadian yang tidak pantas. Hubungan antara komunitas 1 Petrus dengan kekaisaran Romawi benar-benar berbahaya. Mereka

\footnotetext{
${ }^{39}$ Williams, Persecution in 1 Peter, 300. Bandingkan dengan A Home for the Homeless (Elliott 1981, 80).

${ }^{40}$ Fika Janse Van Rensburg, "Constructing the Economic-Historic Context of 1 Peter: Exploring a Methodology" Hervormde Teologiese Studies 67, no. 1 (2011): 7.

41 Williams, Persecution in 1 Peter, 300-301.

42 Annang Asumang, "'Resist Him' (1 Peter 5:9): Holiness and NonRetaliatory Responses to Unjust Suffering as 'Holy War' in 1 Peter," Conspectus (South African Theological Seminary) 11, no. 1 (2011): 38. Bandingkan dengan Persecution in 1 Peter: Differentiating and Contextualizing Early Christian Suffering (Williams 2012, 300).

43 Williams, Persecution in 1 Peter, 301.

44 Betsy J. Bauman-Martin, "Women on the Edge: New Perspectives on Women in the Petrine Haustafel," Journal of Biblical Literature 123, no. 2 (2004): 269.

45 Williams, Persecution in 1 Peter, 301-302.
} 
ditindas dan ditangkap secara paksa. ${ }^{46}$ Merril C. Tenney mengatakan bahwa nada ketakutan menaungi keadaan jemaat Kristen pada masa itu. $^{47}$

Sebenarnya persoalan menjadi Kristen bukanlah ancaman yang terutama, karena status pemeluk agama Kristen tidak bersifat ilegal. Permasalahan yang utama ialah penolakan komunitas 1 Petrus untuk melakukan pengorbanan terhadap dewa-dewa dari agama pagan dan ketidaksediaan mereka untuk bersumpah setia kepada Kaisar. ${ }^{48}$

\section{Identifikasi Trauma dalam Narasi Traumatis Kaum Perempuan Timor Timur dan Komunitas 1 Petrus}

Narasi kaum perempuan Timor Timur dan komunitas 1 Petrus tidak hanya sebatas narasi kekerasan. Narasi kekerasan itu bergerak menuju dan menjadi suatu narasi traumatis. Trauma merupakan dampak dari kekerasan. Kata trauma berasal dari kata Yunani trau/ma yang berarti luka atau luka pada tubuh yang disebabkan oleh kekerasan. Definisi tersebut menekankan pada luka fisik, namun studi kontemporer mengenai trauma memperluas penerapannya pada aspek psikis, yakni pikiran dan emosi. ${ }^{49}$ Judith Herman menggunakan istilah kata yang tidak dapat diucapkan - the word unspeakable - untuk menjelaskan tentang trauma. ${ }^{50}$

Kekerasan kaum perempuan Timor Timur dan kekerasan komunitas 1 Petrus menghasilkan trauma pada diri mereka, baik secara personal maupun komunal. Tujuh karakteristik trauma yang dikemukakan oleh Serene Jones berdasarkan pandangan Bessel van der Kolk dan Judith Herman membantu saya untuk mengidentifikasi trauma sebagai karater naratif dari dua cerita tersebut.

Pertama, peristiwa traumatis dapat dibedakan berdasarkan besarnya. ${ }^{51}$ Peristiwa tersebut bukanlah peristiwa yang dengan sederhana membuat seseorang sedih, tidak nyaman, dan merasa kehilangan. Peristiwa traumatis adalah peristiwa ketika seseorang mengalami ancaman untuk dihancurkan atau dibinasakan. ${ }^{52}$

${ }^{46}$ Ibid., 303.

${ }^{47}$ Merrill C. Tenney, New Testament Times (United States of America: Wm.

B. Eerdmans Publishing Co., 1965), 322.

48 Williams, Persecution in 1 Peter, 198.

${ }^{49}$ Serene Jones, Trauma and Grace: Theology in a Ruptured World (Louisville, Kentucky: Westminster John Knox Press, 2009), 12.

${ }^{50}$ Judith Lewis Herman, Trauma and Recovery (New York: Basic Books, 1997), 1.

\footnotetext{
51 Jones, Trauma and Grace, 13.
}

52 Ibid. 
Dalam narasi perempuan Timor Timur, kasus kekerasan yang dilakukan oleh tentara Indonesia memunculkan keresahan di setiap kalangan, secara khusus perempuan. Tentara Indonesia membentuk organisasi-organisasi milisi. Semua anggota milisi adalah orang-orang Timor Timur. Mereka dilatih, dipersenjatai, dan diberikan fasilitas untuk menindas bangsanya sendiri. Banyak dari mereka diberikan kekuasaan untuk mengintimidasi dan melakukan tindakan kriminal tanpa risiko berhadapan dengan hukum (impunity). ${ }^{53}$

Waktu itu hari Jumat 3 September. Saya mulai merasa tidak aman, kemudian saya pergi mengungsi ke susteran di Aimutin. Di sana hanya ada sedikit pengungsi, hanya ibu-ibu hamil saja. Suster bilang kepada saya agar tidak keluar kamar, takut kalau ada yang berhasil mengenali saya. Tetapi saya merasa tidak tenang.

Esoknya, Sabtu 4 September, saya minta ijin pulang ke rumah karena saat itu saya tidak membawa apa-apa kecuali baju di badan dan anak-anak saja. Di tengah jalan, saya bertemu dengan penjual tahu tempe tetangga saya. Dia bertanya, "Ibu mau pergi kemana?" Saya bilang, "Saya mau pulang ke rumah." Dia kemudian melarang saya karena saya dan keluarga saya dicari-cari dan rumah saya sudah dihancurkan para milisi...

Setelah saya bertemu suami saya, kemudian saya kembali ke Aimutin lagi sambil menerima mati saja karena kondisi betulbetul mencekam. Milisi berkeliaran di jalan-jalan sambil menembak-nembak ke segala arah. Sesampainya saya di biara Aimutin, saya... bersembunyi bersama tiga orang anak saya di kamar mandi. Saya buka tikar dan saya baringkan anak-anak... di kamar mandi. Saya rapikan kamar agar ketika mendobrak kamar, mereka akan menyangka tidak ada orang. Tembakan terus menerus terdengar sampai pagi. Kemudian pagi-pagi suster mengusulkan agar kami... pergi ke Kupang... Kami ke luar dari Dili hari Senin, 6 September 1999, naik kapal perang...

Di pelabuhan saya lihat banyak sekali milisi Aitarak berkeliaran memeriksa orang-orang yang naik kapal. Tangan saya sempat ditarik oleh milisi ketika naik kapal, untung suster bilang, "Hey jangan, itu kakak ipar saya dari Flores!” Mereka kemudian

53 Campbell-Nelson, Perempuan Dibawa/h Laki-Laki yang Kalah, 22. 
melepaskan saya... Di dalam kapal itu terdapat banyak milisi yang mencari orang-orang pro-kemerdekaan... Tiba di Atapupu, kami dijemput keluarga suster... Setelah semalam tinggal di Atapupu kami... naik bis ke Kupang...

Di Atambua bis berhenti untuk mengisi bahan bakar. Di sana saya menyaksikan kejadian mengerikan. Saya melihat ada dua orang diikat di dalam truk oleh milisi Aitarak. Di dalam truk tersebut bukan hanya berisi dua orang yang diikat tetapi juga para milisi. Tiba-tiba di depan orang banyak, salah seorang milisi dengan penuh gaya menghunus pedang perlahan-lahan. Seolah ingin menunjukkan kebolehannya, pelan-pelan dia menusuk orang pertama yang diikat di dalam truk. Darah mengucur banyak sekali, membanjiri lantai truk hingga menetes ke luar. Satu orang lagi diikat kedua tangan dan kakinya seperti babi. Mereka melempar orang tersebut seperti orang membuang beras ke aspal. Kemudian dari aspal dilempar lagi ke truk yang lain. Saya tidak tahu lagi kelanjutannya karena kemudian bis berangkat ke Kupang. Di dalam bis saya menangis melihat kebiadaban mereka. ${ }^{54}$

Narasi di atas hanya menceritakan satu dari berbagai narasi perempuan Timor Timur yang diperhadapkan dengan situasi yang mengancam diri sendiri bahkan keluarga mereka. Perasaan sedih, panik, takut, tidak berdaya, ingin mati tergambar jelas pada narasi di atas.

Dalam komunitas 1 Petrus, penyiksaan yang dilakukan terhadap orang Kristen membuat banyak orang Kristen merasa hidupnya terancam. Dalam 1 Petrus 5:8 terdapat gambaran singa yang mengaum-aum. Gambaran tersebut bukan hanya menjelaskan bahaya yang mengancam komunitas 1 Petrus, tetapi juga menyatakan salah satu bentuk eksekusi ${ }^{55}$ yang dihadapi oleh komunitas Kristen. Narasi kekerasan kaum perempuan Timor Timur dan komunitas 1 Petrus secara jelas memperlihatkan situasi ketika mereka berada di dalam ancaman, bahkan ketika mereka mengalami kekerasan tersebut.

Kedua, suatu peristiwa menjadi traumatis ketika seseorang merasa atau membayangkan kehidupannya terancam karena sesuatu hal, walaupun tidak mengalaminya secara langsung. ${ }^{56}$ Dalam narasi perempuan Timor Timur, ada begitu banyak perempuan yang menangis ketakutan bahkan langsung mengubah penampilan mereka

\footnotetext{
54 Ibid., 33-35.

55 Eksekusi dengan melemparkan jemaat Kristen ke dalam suatu arena yang dipenuhi oleh singa-singa yang mengaum-aum (Horrell 2013, 716).

${ }^{56}$ Jones, Trauma and Grace, 14.
} 
karena takut diperkosa. Banyak orang Timor Timur, termasuk perempuan dan anak-anak yang berusaha untuk meninggalkan Timor Timur karena begitu banyak tindak kejahatan yang terjadi, seperti pembunuhan, pembakaran, perampokan, penjarahan, dan pemerkosaan. ${ }^{57}$

Maggie O'Kane dari London The Guardian mengatakan bahwa pada 20 September 1999, Timor Timur telah dijarah, dirusak, dan dikosongkan karena ditinggalkan penduduknya. Satu-satunya yang tinggal di Timor Timur adalah orang-orang yang terlalu takut untuk pindah. Mereka adalah perempuan dan anak-anak. Mereka menjadi orang pantai, namun di sepanjang pantai bau busuk tahi berbaur dengan bau ratusan panci beras. ${ }^{58}$

Dalam komunitas 1 Petrus, situasi yang mencekam membuat penulis surat memperingatkan para anggota komunitas untuk bertahan dalam situasi sulit. Ada dua kemungkinan yang melatarbelakangi peringatan tersebut, yakni mereka yang menderita siksaan tidak dapat bertahan dan memutuskan untuk meninggalkan iman kepada Kristus atau mereka yang belum menderita siksaan, namun ingin meninggalkan iman kepada Kristus karena merasa terancam.

Ketiga, trauma biasanya didasarkan dalam peristiwa yang konkrit, meskipun memori individu yang mengalami peristiwa tersebut tidak stabil. ${ }^{59}$ Kekerasan yang dialami oleh kaum perempuan Timor Timur dan komunitas 1 Petrus adalah suatu peristiwa yang konkrit. Kasus pemerkosaan yang dialami oleh kaum perempuan Timor Timur mengakibatkan banyak korban pemerkosaan terjun menjadi pekerja seks komersial karena merasa dirinya kotor dan tidak diterima oleh masyarakat. Ada juga yang menjadi gila karena stres.

Women who had been raped were more likely to suffer symptoms of trauma than other victims of violations. This may partly be because many women raped or forced into situations of sexual slavery by the Indonesian military reported that they were shunned by their family and community, and thereby lost the support necessary for healing and mental well-being. The plight of women who had children as a result of rape, or being in a situation of sexual slavery, was even worse. There are communities, such as Suai, where women were subjected to

${ }^{57}$ Campbell-Nelson, Perempuan Dibawa/ h Laki-Laki yang Kalah, 135.

58 Joseph Nevins, Pembantaian Timor Timur: Horor Masyarakat Internasional (Yogyakarta: Galangpress, 2008), 4-6.

59 Jones, Trauma and Grace, 14. 
mass rape after the Popular Consultation in 1999, where large numbers of women are in need of support. ${ }^{60}$

Pada pihak lain, penolakan komunitas 1 Petrus untuk melakukan pengorbanan terhadap dewa-dewa dari agama pagan dan ketidaksediaan mereka untuk bersumpah setia kepada Kaisar menyebabkan permusuhan dari masyarakat non-Kristen tercipta. Masyarakat non-Kristen mengganggap jemaat Kristen sebagai pengganggu kedamaian.

Christians considered their communities of faith to be selfcontained groups that made exclusive demands on the individual member. People were to leave behind their former associations to join the church. This involved abandoning their earlier religious affiliations and, if necessary, their own families. Christians claimed that their Lord himself had meant to disrupt the normal family lives of his followers. ${ }^{61}$

Anggapan buruk tentang jemaat Kristen menghasilkan konflik. Status jemaat Kristen selama abad I ZB sampai abad III ZB menjadi effectively illegal. ${ }^{62}$ Kepercayaan Kristen menjadi sebuah pelanggaran yang hanya dapat dihukum di pengadilan gubernur, namun dalam pengadilan tersebut, penderitaan dari penyiksaan tidak terelakkan. Komunitas 1 Petrus menghadapi penderitaan yang konkrit.

Keempat, peristiwa traumatis dapat menimpa mereka yang bukan korban, tetapi merupakan saksi dari peristiwa tersebut. ${ }^{63}$ Liliana, seorang gadis berusia 13 tahun adalah saksi mata teror September 1999 di Dili, Timor Timur.

Ia... menyaksikan kepala-kepala, yang terpisah dari badannya, menggelinding di tanah. Ratusan orang ada di sana bersamanya, menyaksikan kengerian itu. Orang menjerit-jerit dan berusaha melarikan diri dari orang-orang yang menyerang, menusuk, membacok, dan memenggal kepala rekan-rekan sebangsa Liliana. Tetapi kepala-kepala di tanah menciptakan pemandangan yang lain. "Sepertinya mereka sedang bermain sepak bola," kenangnya...

\footnotetext{
${ }^{60}$ Comissão de Acolhimento Verdade e Reconciliação Timor Leste (CAVR), Chega! The Report of the Commission for Reception, Truth, and Reconciliation Timor-Leste Executive Summary, 44-45.

${ }^{61}$ Bart D. Ehrman, The New Testament: A Historical Introduction to the Early Christian Writings, 2nd ed.(New York: Oxford University Press, 2000), 394.

${ }^{62}$ Williams, Persecution in 1 Peter, 194.

${ }^{63}$ Jones, Trauma and Grace, 14.
} 
Ibu dari Liliana mengatakan bahwa ia menutup mata ketika pembunuhan-pembunuhan itu dimulai, karena tidak tahan, tetapi Liliana dan saudara-saudaranya tetap membuka mata. "Mereka tidak mau makan selama beberapa hari sesudahnya." Sampai sekarang, menurut sang ibu, Liliana kadang-kadang masih mengalami mimpi buruk yang berhubungan dengan apa yang dilihatnya. ${ }^{64}$

Dalam narasi komunitas 1 Petrus, penderitaan yang dialami oleh orang Kristen membuat banyak orang Kristen meninggalkan iman mereka daripada mati karena iman. ${ }^{65}$ Pernyataan tersebut menegaskan bahwa saksi dari peristiwa penganiayaan anggota komunitas 1 Petrus tidak mungkin tidak mengalami trauma.

Kelima, peristiwa traumatis dapat menimpa individu maupun komunitas, baik itu pedesaan, bangsa, ataupun keluarga. ${ }^{66}$ Dalam narasi kekerasan kaum perempuan Timor Timur, kekerasan tidak hanya bersifat individu, karena kekerasan tersebut mengancam bahkan menimpa seluruh masyarakat Timor Timur, tak terkecuali komunitas perempuan Timor Timur. Dalam komunitas 1 Petrus, kekerasan justru hanya ditujukan kepada komunitas Kristen yang tidak bersedia untuk melakukan pengorbanan kepada dewa-dewa dan tidak bersedia bersumpah setia kepada Kaisar.

Keenam, peristiwa traumatis tidak hanya terbatas pada satu peristiwa besar. ${ }^{67}$ Ia dapat hadir karena peristiwa yang terjadi berulangulang dalam variasi intensitas yang rendah, misalnya pada kasus kekerasan dalam rumah tangga. Kekerasan yang dialami oleh perempuan Timor Timur merupakan kekerasan yang terjadi berulangulang. Chega! menyebutkan bahwa perempuan Timor Timur berusia muda yang dipaksa bekerja bagi tentara Indonesia, diperkosa secara rutin dan dipaksa untuk hidup dalam perbudakan secara seksual. ${ }^{68}$ Mereka mengalami trauma. Trauma tersebut tidak hanya disebabkan oleh perbudakan seksual, tetapi juga disebabkan oleh sikap keluarga dan komunitas yang menarik diri dari mereka. ${ }^{69}$

Pada pihak lain, Surat 1 Petrus adalah teks yang kemungkinan besar ditulis pada masa pemerintahan Domitianus. Tidak ada bukti spesifik dalam sejarah kekaisaran Romawi tentang penyiksaan terhadap

${ }^{64}$ Nevins, Pembantaian Timor Timur, 4.

${ }^{65}$ Williams, Persecution in 1 Peter, 229.

${ }^{66}$ Ibid., 14-15.

${ }^{67}$ Jones, Trauma and Grace, 15.

${ }^{68}$ Comissão de Acolhimento Verdade e Reconciliação Timor Leste (CAVR), Chega!, 113.

${ }^{69}$ Ibid., 44. 
jemaat Kristen pada masa pemerintahan Domitianus. Namun, tidak dapat diragukan bahwa jemaat Kristen mengalami penyiksaan berat pada masa tersebut. ${ }^{70}$

A few vague hints of such persecuting activity have survived. Suetonius records that Domitian "put to death his own cousin, suddenly and on a very slight suspicion, almost before the end of his consulship; and yet Flavius was a man of most contemptible laziness and Domitian had besides openly named his sons, who were young, as his successors...” Dio Cassius, as reported by Xiphilin, a monk of the eleventh century, states that Flavius Clemens, consul in A.D. 95 and a cousin of the emperor, was tried with his wife Domatilla on a charge of atheism. Clemens was executed; his wife was banished. Dio adds that Acilius Glabrio, consul in A.D. 91, had also been exiled, and that a number of person had "gone astray after the manner of the Jews." Ramsay... argues that Clemens, Domatilla, and Acilius Glabrio were prosecuted under the same general charge, and that "atheism" and "going astray after the manner of the Jews" must reflect Christianity. ${ }^{71}$

Surat 1 Petrus menggambarkan relasi komunitas 1 Petrus dan pemerintah yang semakin genting sehingga ancaman atau penindasaan secara paksa tidak dapat dihindari. ${ }^{72}$ Dalam komunitas 1 Petrus, penderitaan terjadi berulang-ulang ketika jemaat Kristen menerima tuduhan dari masyarakat akibat memperlihatkan gaya hidup yang berbeda dari praktik-praktik kemasyarakatan dalam kekaisaran Romawi. Dekrit Kaisar menjadi alasan jemaat Kristen menerima hukuman. $^{73}$ Pada masa pemerintahan Domitianus, penyembahan kepada Kaisar menjadi bagian dari dekrit Kaisar. 1 Petrus 4:12 menyebutkan bahwa siksaan nyala api mengancam komunitas, meskipun ancaman tersebut belum terjadi. 1 Petrus 4:14 mengatakan bahwa nama Kristus adalah alasan komunitas mendapat ancaman.

70 Tenney, New Testament Times, 324.

71 Ibid.

72 Ibid., 322.

${ }^{73}$ Dekrit Kaisar berisi tuntutan bagi semua penduduk yang berada di wilayah kekaisaran Romawi untuk mendeklarasikan kesetiaan terhadap pagan dengan mempersembahkan korban kepada dewa-dewi tradisional, mencurahkan atau menuangkan persembahan anggur kepada dewa, dan mengambil bagian dalam daging kurban. Mereka yang tidak menaati keputusan tersebut diserahkan kepada otoritas yang lebih tinggi untuk menerima hukuman, yakni pengasingan, penyitaan properti, penyiksaan, atau bahkan kematian (Williams 2012, 184). 
Ketujuh, peristiwa traumatis melampui kapasitas kita dalam mengelola dan mengatasi peristiwa tersebut. Kita tidak dapat melawan, bahkan ketika kita melawan, kita gagal. ${ }^{74}$ Trauma menghasilkan beberapa dampak negatif. Dampak itu disebut oleh Jones dan Herman sebagai Post-Traumatic Stress Disorder (PTSD). Adapun dampak tersebut meliputi dampak pada pikiran, emosional, perubahan negatif pada kepribadian, masalah fisik, dan gangguan jiwa. ${ }^{75}$

Kasus pemerkosaan dan penyiksaan yang dialami oleh kaum perempuan Timor Timur adalah bukti ketidakberdayaan mereka terhadap ancaman milisi dan tentara Indonesia. ${ }^{76}$ Ketidakberdayaan tersebut tampak pada kasus pemerkosaan yang dilakukan oleh José Cardoso, seorang komandan milisi Kaer Metin Merah Putih (KMMP) dan rekan-rekannya.

Sometime in May 1999, José Cardoso, about 50 KMMP militia and a few TNI soldiers, armed with automatic weapons, grenades, machetes and knives went to Guda and gave a speech to the villagers. Acting on the information of Sabino Leite, they named Mariana Da Cunha, Victim A, Victim B, and Victim $C$ as FALINTIL supporters. They claimed these four women were supplying FALINTIL with food and were in relationships with its members. At different times, these four women were taken to Lolotoe and detained in Sabino Leite's house. From there, Victims A, B and C were taken to Jhoni Franca's house and then to a hotel in Atambua on 27 June. At this stage the three women had been detained for a number of weeks. At Atambua, it was stated that José Cardoso would have intercourse with Victim A, Bambang Indra with Victim B, and Francisco Noronha with Victim C. On various nights in late June, the three women were injected with medicine they were told would prevent them from getting pregnant. The three victims were then sexually penetrated by the men, with José Cardoso also raping Victim B. The women were threatened that if they did not obey the men they would be killed. ${ }^{77}$

Pemerkosaan tidak pandang bulu. Seorang perempuan berumur 19 tahun diperkosa oleh ayah tirinya. Pemerkosaan tersebut

\footnotetext{
${ }^{74}$ Jones, Trauma and Grace, 15.

75 Ibid., 16-18. Bandingkan dengan Trauma and Recovery (Herman 1997, 8, 51-56, 61) dan Trauma and Transformation (Tedeschi 1995, 20-26).

${ }^{76}$ Rimmer, Gender and Transitional Justice, 137.

77 Ibid., 107-08.
} 
dilakukan beberapa kali dan selalu disertai dengan ancaman pisau dan larangan untuk tidak menceritakan tindakan itu kepada siapa pun. ${ }^{78}$

Pada pihak lain, dalam kamp pengungsian di Timor Barat, pemerkosaan adalah tindak kejahatan yang sangat rentan dialami oleh kaum perempuan Timor Timur. Merry (nama samaran) adalah seorang Ibu asal Bobonaro yang berumur 30 tahun. Merry mengalami hilang ingatan karena melihat anaknya terbunuh saat kerusuhan pasca jajak pendapat. Pada kamp pengungsian, ia diperkosa oleh seorang pria bernama Ose yang sehari-hari bekerja sebagai tukang ojek di Atambua. Ose selalu menjemput Merry yang tinggal di Kamp Asueman, Atambua dan membawanya ke suatu tempat di sekitar tempat pengungsian untuk diperkosa. ${ }^{79}$

Pada awalnya kaum perempuan Timor Timur memilih untuk tertutup dan atau kurang terbuka dalam menghadapi trauma. Tidak mudah bagi mereka untuk mengungkapkan kekerasan dan penderitaan yang dialami. Bagi mereka, menceritakan persoalan pribadi apalagi yang berhubungan dengan kasus pemerkosaan adalah hal yang tabu. Pemerkosaan dianggap sebagai sebuah aib yang memalukan jika diketahui oleh orang lain. ${ }^{80}$

Media reports confirm that the 'victims of militia rape and sex slavery continue to bear the scars of post-ballot violence in East Timor, facing ostracism on their return home.' Abuelda Alves of the Timorese NGO FOKUPERS ${ }^{81}$ said bluntly of the women who are able to return home, often with babies who are the product of rape: 'They are viewed as rubbish. Their families are embarrassed. Women who were already married, their husbands reject them.' In this context, the extremely low level of reporting rates by Timorese women, especially those returning from forced deportation to the West Timor camps is unsurprising. Generally women will only speak to nuns or priests, or as lawyers assisting Timorese asylum-seekers have noted, they will not speak to anyone at all. ${ }^{82}$

\footnotetext{
${ }^{78}$ Campbell-Nelson, Perempuan Dibawa/ h Laki-Laki yang Kalah, 95.

79 Ibid., 94.

80 Ibid., 93.

${ }^{81}$ FOKUPERS adalah singkatan dari Forum Komunikasi untuk
} Perempuan Lorosa'e (East Timorese Women's Communication Forum), yang didirikan pada tahun 1997 dan berfokus pada korban-korban politik serta memberikan konseling dan bentuk-bentuk bantuan lainnya kepada perempuan korban pelanggaran hukum, seperti mantan tahanan politik, janda-janda perang, dan istri para tahanan politik (Rimmer 2010, 63).

82 Rimmer, Gender and Transitional Justice, 138. 
Trauma yang dihadapi oleh kaum perempuan Timor Timur juga menyebabkan emosi mereka mudah terpancing dengan amarah yang berlebihan. Tingkat emosi tersebut menimbulkan kekerasan yang baru. Mereka menjadi sangat rentan terhadap sejumlah kekerasan, sekaligus melanjutkan kekerasan tersebut dengan berganti status sebagai pelaku kekerasan. Anak-anak menjadi korban kekerasan dari ibu mereka sendiri. ${ }^{83}$

Ibu LD adalah ibu RT dan istri seorang anggota TNI. Di antara anak-anaknya, hanya satu yang bersekolah. Dua anak lain berusia sekolah, tapi tidak disekolahkan dan empat anak balita sering telanjang, tidak berpakaian, dan jarang mandi. Menurut Ibu LD, sebagai isteri dia harus berlaku menurut apa yang dikatakan suami. Kalau suaminya tidak pernah menyuruh anakanak untuk sekolah, dia tidak akan bertanya atau menyuruh suami untuk menyekolahkan anak-anak. Begitu pula anakanaknya yang tidak selalu berpakaian. Walaupun ia mendapat gaji dari suami, kalau suaminya tidak menyuruhnya untuk membelikan pakaian, Ibu LD pun tidak akan membeli. Dan karena anak-anaknya masih kecil, kalau baju dipakai sebentar saja sudah menjadi kotor sehingga dia malas untuk mencucinya. Kekerasan terhadap anak seperti memukul anakanak, menurut Ibu LD adalah suatu hal yang dianggap wajar, kalau sampai membunuh baru dikatakan salah. ${ }^{84}$

Sama halnya dengan kaum perempuan Timor Timur, trauma mengakibatkan komunitas 1 Petrus pun menjadi suatu komunitas yang tertutup. Namun, pada akhirnya komunitas tersebut tidak membisu. Trauma tidak membuat mereka apatis terhadap anggota komunitas yang mengalami penderitaan. Trauma justru mempererat relasi di antara para anggota. Mereka dipersatukan dalam ideologi household of God.

\section{Narasi Traumatis dan Re-making of Self}

Saat kekerasan menjadikan para korban mengalami peristiwa traumatis, upaya re-making of self pun dimulai. Re-making of self adalah suatu upaya pencarian jati diri, pengungkapan kerapuhan diri, terlibat dengan yang lain untuk menyatakan identitas, dalam hal ini identitas

\footnotetext{
${ }^{83}$ Campbell-Nelson, Perempuan Dibawa/h Laki-Laki yang Kalah, 177.

84 Ibid.
} 
perempuan Timor Timur dan komunitas 1 Petrus. Re-making of self adalah suatu upaya yang tidak meninggalkan ingatan masa lalu.

Menurut R. Ruard Ganzevoort, trauma dapat mengancam identitas, ketika seseorang atau suatu komunitas memilih untuk melupakan peristiwa traumatis tersebut. Sebaliknya, trauma dapat menjadi penanda dari identitas, ketika peristiwa traumatis diterima. Dalam penerimaan itu, luka akibat trauma tidak mengurangi makna dari kehidupan. Ia justru memberi makna tambahan dalam narasi kehidupan. Narasi traumatis akibat kekerasan pun tidak memutuskan relasi antara aku dan yang lain. Tindakan menerima berarti kesediaan untuk mengingat dan membagikan narasi traumatis tersebut kepada yang lain. ${ }^{85}$

Tindakan mengingat sangat penting karena dalam upaya menghindari pertanggungjawaban atas kejahatan, pelaku dapat melakukan apa saja yang bisa dilakukan untuk melupakan. Kerahasiaan dan kebungkaman adalah garis pertahanan pertama pelaku. Kalau kerahasiaan gagal, pelaku menyerang nama baik korbannya. Kalau tidak bisa membungkamnya, ia berusaha memastikan bahwa tidak ada orang yang mendengarkan suara korbannya. Dalam rangka mencapai tujuan tersebut, pelaku mengumpulkan banyak argumen, dari pengingkaran paling terang-terangan sampai rasionalisasi yang paling canggih dan indah. Semakin berkuasa pelaku, semakin besar kekuatannya untuk menyebutkan dan mendefinisikan kenyataan serta semakin kuat argumen-argumen yang diberikan. ${ }^{86}$

Upaya re-making of self terjadi ketika korban bergerak maju melampaui narasi traumatis dengan tidak melupakan peristiwa traumatis yang dialami. Narasi traumatis kaum perempuan Timor Timur mengungkapkan bahwa pada awalnya pilihan yang diambil adalah tertutup. Pilihan tersebut dipengaruhi oleh budaya, situasi tempat tinggal, tidak adanya jaminan hukuman, dan aib yang dirasakan akibat peristiwa traumatis yang dialami. Meskipun ada yang berani untuk mengungkapkan narasi traumatis, namun pengungkapan tersebut dilakukan secara diam-diam.

Masyarakat Timor Timor, secara khusus kaum perempuan Timor Timur hidup dalam keadaan traumatis. Jika keadaan traumatis tersebut tidak diselesaikan, maka Timor Timur berhadapan dengan situasi yang lebih buruk. Situasi yang saya maksudkan ialah situasi saat masyarakat Timor Timur kehilangan identitas. Situasi itu menunjuk pada kondisi masyarakat Timor Timur yang tidak mampu memandang diri sendiri sementara pihak lain memandang mereka berdasarkan

85 R. Ruard Ganzevoort, "Scars and Stigmata: Trauma, Identity, and Theology," Practical Theology 1, no. 1 (2008): 3,6.

86 Nevins, Pembantaian Timor Timur, 182. 
identitas yang diberikan oleh pihak yang menindas. Perjuangan untuk melampaui masa lalu mutlak diperlukan. Perjuangan tersebut secara inheren terikat dengan perjuangan mengenai identitas. Timor Timur harus bangkit dan menyelesaikan permasalahan yang terjadi.

Penderitaan Timor Timur akibat periode kekerasan sekaligus traumatis karena perang saudara yang terjadi akibat kekuasaan militer di Timor Timur tidak boleh dilupakan. Ingatan masa lalu diperlukan dalam upaya rekonsiliasi. Melalui ingatan masa lalu, Timor Timur dapat bergerak maju untuk membangun masa depan yang lebih baik. Upaya untuk tidak melupakan sejarah serta membangun kembali hubungan antar-rakyat Timor Timur yang rusak karena konflik mendorong Timor Timur mendirikan CAVR (Commissāo de Acolbimento, Verdade e Reconciliaçāo alias Komisi Penerimaan, Kebenaran, dan Rekonsiliasi).

CAVR adalah lembaga Timor Timur yang dipimpin oleh tujuh komisaris berkebangsaan Timor. Ide tentang CAVR digagas pada tahun $2000 .^{87}$ CAVR dimandatkan untuk menjalankan tiga tugas utama, yakni menetapkan kebenaran tentang pelanggaran hak asasi manusia yang dilakukan semua pihak selama 1974-1999 dalam konteks konflik mengenai status politik Timor Timur, memfasilitasi rekonsiliasi antara komunitas dan pelaku kejahatan ringan serta korban mereka, dan membuat laporan mengenai pekerjaan, temuan-temuan, dan rekomendasi CAVR. Laporan CAVR tersebut berjudul Chega. ${ }^{\beta 8}$

Melalui peran CAVR dan berbagai pihak yang mendukung, salah satunya Tim Kemanusiaan Timor Barat, masyarakat Timor Timur, terkhususnya perempuan Timor Timur dapat mengubah pilihan untuk tertutup menjadi kesediaan untuk bersuara tentang penderitaan yang dialami. Perempuan Timor Timur berjuang untuk bebas dari segala bentuk peristiwa traumatis yang dialami.

One of the bravest but least known acts during the East Timorese resistance to Indonesian occupation occurred in November 1998 when over 20 Timorese women told their stories of surviving sexual violence to crowds of hundreds at a public meeting in Dili. The stories were collated into an English language book called Buibere, which means 'woman' in Mumbai, the second most common Timorese language after Tetum. It was written only in English, published in Australia, and intended as an advocacy document for the international community. Between 1975 and 1999, there had only been four short but searing reports from international non-governmental

${ }^{87}$ Comissão de Acolhimento Verdade e Reconciliação Timor Leste (CAVR), Chega!, 8.

${ }^{88}$ Walsh, Di Tempat Kejadian Perkara, 230-31. 
organisations (NGOs) about gender-based persecution of women in East Timor, and no official United Nations (UN) comment. But the persecution, as described first-hand in these collected testimonies, was intense, and included rape, torture and other inhumane acts. In November 2001, in an independent East Timor, the local women's rights NGO FOKUPERS released a second version of Buibere in Tetum at a public event, with many of the women who contributed stories to the book present. The second edition is intended to formally respect and honour the contribution of East Timorese women to independence and the high price they paid during the Indonesian occupation. ${ }^{89}$

Perempuan Timor Timur mengalami re-making of self. Mereka tidak lagi takut untuk membagikan cerita tentang teror, kekejaman, kematian, keberanian, ketulusan hati, dan upaya untuk bertahan hidup pada hari-hari terakhir pendudukan Indonesia. Mereka memiliki harapan setelah dua puluh empat tahun menderita.

Joseph Nevins menceritakan pengalamannya ketika ia mengunjungi Ana Lopes pada pertengahan tahun 2000 di puing-puing rumah keluarga Lopes di salah satu kampung Dili yang paling hancur. Nevins berkata,

Ia tertawa ketika berbicara, mengungkapkan dirinya dengan rasa lega dan percaya diri... Ia berbicara kepada saya untuk pertama kalinya dengan suara yang lebih keras daripada bisikan lirih. Berbeda dengan 1999, ketika milisi terus-menerus menerornya. Ia tidak lagi gemetar duduk di kursinya dalam diskusi kami. Ia juga tidak menangis ketika kami berbicara. Ketika saya pergi, ia berjalan mengiringi saya keluar rumah sampai jalan - sesuatu yang tidak pernah dilakukannya dalam kunjungan saya tahun sebelumnya karena takut membuat geram milisi yang mengancam kampung. Kali ini Ia menyeberang jalan dan dengan bangga menunjukkan kepada saya jagung yang ditanamnya di kebun di seberang rumahnya, di tengah puing-puing pos milisi. ${ }^{90}$

Masyarakat Timor Timur, terkhususnya perempuan Timor Timur pun dikuatkan melalui kehadiran Presiden Xanana Gusmão. Presiden Gusmão mengajarkan kepada mereka tentang cinta dan rekonsiliasi.

${ }^{89}$ Rimmer, Gender and Transitional Justice, 16.

${ }^{90}$ Nevins, Pembantaian Timor Timur, 277. 
President Gusmão... told a conference in Berlin that his stance was pragmatic: We fought for 24 years and during the struggle we followed many other conflicts, some of them ended, some of them are on the way to [an] end. Two and a half years after independence we are ahead of Guinea Bissau, a former Portuguese colony which was the first to start its independence struggle, and they still face human rights abuses and poverty. With our policy we have security, stability and progress. We have good relations with our big neighbour. NGOs say, on behalf of victims there must be justice. For our process, real justice was that the international community recognized our independence and helped to achieve it. For all the sacrifices of our people, our obligation is to bring them real independence, meaning social justice and development. East Timor should not live in the past, but look towards the future. Then President Gusmão's reconciliation attempts reached their apex with 'Operasaun Domin' (Operation Love), which collected $\$ 77,000$ from Timor Leste people for tsunami victims, and then presented it as a personal gift to President Susilo Bambang Yudhoyono. ${ }^{91}$

Narasi traumatis perempuan Timor Timur hadir untuk menyatakan bahwa narasi personal jalin-menjalin dengan narasi komunal. Narasi kekerasan personal perempuan Timor Timur berdampak bagi narasi komunal perempuan Timor Timur bahkan narasi komunal masyarakat Timor Timur. Semua perempuan Timor Timur mengalami peristiwa traumatis, namun kekuatan dari individu/kelompok yang satu memberanikan individu/kelompok yang lain untuk bangkit dari peristiwa traumatis. Narasi yang personal dan komunal tidak dapat dipisahkan.

Narasi komunitas 1 Petrus memperlihatkan suatu komunitas yang berhasil bangkit dari peristiwa traumatis karena digerakkan oleh harapan. Harapan tersebut terkandung dalam ideologi household of God. Menurut Elliott, ideologi adalah suatu konsep dari suatu sistem kepercayaan, asumsi, dan nilai-nilai, yang merefleksikan kebutuhan dan kepentingan dari kelompok atau kelas pada suatu waktu yang partikular dalam sejarah. Ideologi dibentuk oleh perspektif-perspektif khusus terhadap realita-realita yang dibagikan oleh kelompok, berkaitan dengan dunia, masyarakat dan manusia, keterbatasan, serta potensi dari eksistensi manusia. Perspektif-perspektif tersebut dikondisikan melalui pengalaman dan harapan untuk menyatukan individu-individu dalam suatu komunitas yang siap dan akan melakukan tindakan-tindakan yang

${ }^{91}$ Rimmer, Gender and Transitional Justice, 153-54. 
telah disetujui bersama untuk mencapai nilai serta tujuan bersama. ${ }^{92}$ Ideologi household of God lahir dari pergulatan iman komunitas 1 Petrus.

Komunitas 1 Petrus adalah komunitas yang menderita akibat keterasingan yang dilakukan oleh masyarakat non-Kristen. Penderitaan itu membuat penulis 1 Petrus bertindak. Ada tiga tindakan yang dilakukan oleh penulis surat. Tindakan pertama adalah hadir. Penulis surat hadir dalam komunitas 1 Petrus, komunitas yang mengalami peristiwa traumatis. Kehadiran penulis surat tampak dalam sapaan penulis kepada setiap kelompok dalam komunitas 1 Petrus. Dalam 1 Petrus 2:18-3:7, penulis surat menggunakan kata oivke,tai. Oivke,tai adalah sapaan yang menyatakan bahwa penulis surat mengetahui identitas penerima surat dan isu ketidakadilan yang dihadapi.

Kata oivke,tai memiliki keterhubungan dengan kata oikoj yang menunjuk kepada para pekerja dalam rumah tangga. ${ }^{93}$ Keterhubungan tersebut menyatakan dua hal, yakni: 1) kehadiran oivke,tai tidak terpisah dari rumah. Mereka adalah bagian dari rumah dan tidak hanya sebatas anggota dari kelas sosial tertentu; dan 2) mereka adalah anggota keluarga. Namun, dalam rumah tangga, oivke,tai justru tidak diperlakukan sebagai saudara. Oivke,tai dianggap sebagai harta milik. Oivke,tai diberi status asing bahkan mungkin tidak dikenal di rumahnya sendiri. Status tersebut mengakibatkan oivke,tai menderita.

Kehadiran penulis surat juga tampak melalui tindakan penulis surat untuk menasihati, membesarkan hati, dan menguatkan komunitas Kristen di Asia Kecil. ${ }^{94}$ Ia mendorong mereka untuk teguh dalam pencobaan-pencobaan yang terjadi. ${ }^{95}$ Penulis surat pun berharap agar setiap penerima surat mengetahui identitas mereka dan tetap memelihara identitas diri sebagai seorang Kristen. ${ }^{96}$ Surat 1 Petrus adalah bukti kehadiran penulis surat dalam kehidupan komunitas 1 Petrus.

Tindakan kedua yang dilakukan oleh penulis surat adalah mendengarkan narasi. Melalui tindakan mendengar, penulis surat mengetahui dan memahami situasi yang dialami oleh komunitas 1 Petrus. Melalui tindakan mendengar, penulis surat secara sengaja menyapa salah satu kelompok dalam komunitas tersebut dengan istilah

92 Elliott, A Home for the Homeless, 269-296.

${ }^{3}$ Mark Dubis, 1 Peter: A Handbook on the Greek Text (Waco, Tex.: Baylor University Press, 2010), 71.

94 Udo Schnelle, The History and Theology of the New Testament W ritings (Minneapolis, MN: Fortress Press, 1998), 407.

95 Willi Marxsen, Pengantar Perjanjian Baru: Pendekatan Kritis terhadap Masalah-Masalahnya (Jakarta: BPK Gunung Mulia, 2012), 293.

${ }^{96}$ Schnelle, The History and Theology of the New Testament Writings, 413. 
oivke,tai bukan dengan istilah dou/lor ${ }^{97}$. Melalui tindakan mendengar, penulis surat memberi nasihat yang sesuai dengan permasalahan komunitas 1 Petrus.

Tindakan ketiga yang dilakukan oleh penulis surat adalah merekonstruksi narasi. Setelah mendengarkan narasi komunitas 1 Petrus, penulis surat bertindak. Seluruh narasi dalam surat 1 Petrus pun ditulis dalam kerangka household of God. Kerangka tersebut memuat ideologi household of God, suatu ideologi yang lahir dari rekonstruksi narasi traumatis komunitas 1 Petrus. Dalam 1 Petrus 2:18-25, penulis surat merekonstruksi narasi penderitaan oivke,tai dengan berdasar pada penderitaan Kristus untuk menyatakan bahwa oivke,tai adalah bagian dari rumah, sehingga oivke,tai berhak untuk dikenal, dicintai, dan dilindungi.

Ideologi household of God memberi komunitas 1 Petrus identitas sebagai umat Allah. Ideologi tersebut juga mempersatukan mereka yang terasing dalam suatu komunitas yang menjunjung tinggi semangat persaudaraan. ${ }^{98}$ Pada komunitas tersebut, semua orang yang tidak berumah, yaitu mereka yang disebut pa,roikoj danparepi,dhmoj memperoleh rumah.

Ideologi household of God mengingatkan bahwa panggilan komunitas 1 Petrus ialah meneladani Kristus. Panggilan tersebut memungkinkan komunitas 1 Petrus untuk mencintai orang yang memberikan tuduhan palsu atas mereka, mencintai orang yang menyiksa mereka atau bahkan saudara-saudara mereka sampai mati. Komunitas 1 Petrus mampu mencintai setiap orang yang berbuat jahat karena iman kepada Allah.

Tindakan mencintai yang dilakukan oleh komunitas 1 Petrus adalah tindakan perlawanan terhadap pihak yang menindas. Dalam 1 Petrus 2:15, penulis surat secara eksplisit menyatakan bahwa perbuatan baik merupakan kehendak dari Allah untuk membungkam kepicikan orang-orang yang bodoh. Tindakan mencintai tersebut adalah tindakan perlawanan terhadap penderitaan yang diterima oleh komunitas 1 Petrus akibat ketidakadilan dalam kekaisaran Romawi.

Melalui peran penulis surat, komunitas 1 Petrus dapat bersuara terhadap penderitaan dan melawan penderitaan dengan jalan cinta. Komunitas 1 Petrus mampu mengatasi pagar-pagar ketakutan dan

${ }^{97}$ Kata oivke,tai mengandung kepelbagaian kelas sosial, karena kata oivke,tai menunjuk kepada budak dan non-budak, baik itu seorang hamba yang merdeka atau freedman/-woman. Karakteristik tersebut berbeda dengan kata dou/loi yang berasal dari kata $d b$, [, dan seharusnya diterjemahkan sebagai hamba atau abdi dan bukan budak.

98 Ibid., 283. 
menggapai sesama saudara laki-laki dan perempuan yang mengalami kesukaran dengan semangat solidaritas persaudaran.

Komunitas 1 Petrus berjuang untuk hidup dan mengatasi trauma yang dihadapi. Narasi perjuangan tersebut bukan narasi ketidakberdayaan dari orang-orang yang tidak mampu melawan kekuasan yang menindas. Narasi perjuangan komunitas 1 Petrus adalah narasi perlawanan karena tidak ingin terbelenggu dalam ketakutan, ketidakadilan, dan penindasan. Perjuangan komunitas 1 Petrus adalah usaha untuk menjelaskan siapa mereka dan apa yang harus mereka lakukan. Komunitas 1 Petrus mengalami re-making of self.

Perempuan Timor Timur dan komunitas 1 Petrus membuktikan bahwa transformasi dari trauma atau re-making of self dimulai dengan menemukan kembali narasi di balik trauma. Penemuan tersebut hanya dapat terjadi melalui mengingat, berkata dengan jujur, dan terlibat bersama orang lain.

\section{Identitas Sosial Kristen yang Terbuka}

Re-making of self membentuk identitas. Richard Jenkins mengatakan bahwa identitas adalah suatu proses. Proses tersebut melibatkan pemahaman kita tentang diri sendiri maupun pemahaman orang lain tentang kita.

As a very basic starting point, identity is the human capacity rooted in language - to know 'who's who' (and hence 'what's what'). This involves knowing who we are, knowing who others are, them knowing who we are, us knowing who they think we are, and so on: a multi-dimensional classification or mapping of the human world and our places in it, as individuals and as members of collectivities. It is a process - identification - not a 'thing'. It is not something that one can have, or not; it is something that one does. ${ }^{99}$

Identitas memengaruhi kehidupan sehari-hari. Identitas menentukan cara kita melihat dunia. Identitas menentukan individu diterima, diabaikan, atau ditindas oleh pihak lain. Narasi perempuan Timor Timur dan komunitas 1 Petrus membuktikan bahwa persoalan identitas, yakni persoalan siapa kita dan bagaimana kita dilihat oleh orang lain adalah persoalan yang sangat penting.

${ }_{99}$ Richard Jenkins, Social Identity, 3rd ed. (London; New York: Routledge, 2008), 5 . 
Menurut Jenkins, semua identitas manusia adalah identitas sosial. Identitas adalah mengenai makna dan makna selalu melibatkan interaksi sosial: setuju dan tidak setuju, kebiasaan dan inovasi, komunikasi dan negosiasi. ${ }^{100}$ Pada pihak lain, Robert L. Montgomery menggunakan istilah persepsi. Menurutnya, identitas sosial menekankan pada persepsi dari anggota-anggota kelompok dan hubungan antarkelompok. ${ }^{101}$ Henri Tajfel mengatakan bahwa identitas sosial adalah bagian dari konsep diri seseorang yang berasal dari pengetahuannya sebagai anggota kelompok sosial. ${ }^{102}$ Identitas diri jalinmenjalin dengan identitas sosial karena setiap proses identifikasi hadir dalam hubungan saya bersama orang lain bahkan ciptaan lain.

Diri kita, masyarakat, bahkan bangsa sekalipun dibentuk oleh begitu banyak pengalaman negatif. Peristiwa traumatis menghasilkan makna/persepsi/pengetahuan yang berdampak pada identitas. Dalam narasi perempuan Timor Timur, perempuan Timor Timur mengidentifikasi diri sebagai perempuan yang berjuang melawan lupa untuk memperoleh keadilan dan perempuan yang berani mencintai dengan memaafkan para pelaku kejahatan. Identifikasi tersebut berguna agar setiap orang belajar dari pengalaman traumatis dan berupaya agar pengalaman tersebut tidak terulang demi membangun masa depan Timor Timur.

José Ramos-Horta dan Xanana Gusmão memberi sumbangsih pada identitas perempuan Timor Timur. Keduanya menekankan pada kebutuhan rakyat Timor Timur untuk memaafkan mereka yang melukai.

Dalam dokumenter mengenai karir diplomatiknya, The Diplomat, José Ramos-Horta difilmkan tengah menonton perusakan di Dili pada 1999. Dengan amarah dia berkomentar, "Harus ada pengadilan pidana perang. Akan ada seratusan dari mereka yang mengantri untuk diadili." Tetapi di tempat kejadian ia kemudian berkata kepada pasukan gerilya TimorLeste, "Kita seharusnya tidak membenci mereka (militer Indonesia). Kita harus memaafkan mereka, mengulurkan tangan, dan menawarkan hati kita kepada mereka. Bila kita melakukan ini, Timor Timur akan menjadi tempat yang lebih baik." 103

100 Ibid., 17.

101 Robert L. Montgomery, Introduction to the Sociology of Missions (Westport, Conn.: Praeger, 1999), 83.

102 Ibid., 84-85.

103 Walsh, Di Tempat Kejadian Perkara, 303-04. 
Pada pihak lain, gereja pun memberi sumbangsih pada identitas perempuan Timor Timur. Gereja menyatakan bahwa keadilan tidak dapat dilupakan. Bagi umat Kristen, pemaafan bukanlah imunitas. Pemaafan membutuhkan keadilan. Keadilan tidak bisa dipisahkan dari cinta, persaudaraan, dan solidaritas, faktor-faktor yang mempromosikan rekonsiliasi. Itu sebabnya di dunia sekarang ini keadilan dan rekonsiliasi berjalan beriringan. Tak akan ada perdamaian sejati dan abadi tanpa keadilan.

Identitas perempuan Timor Timur berjuang untuk mencintai dan memperoleh keadilan adalah identitas yang terbuka untuk diterapkan dalam masyarakat. Identitas tersebut tidak bersifat eksklusif. Identitas perempuan Timor Timur terkait erat dengan identitas kita.

Dalam narasi komunitas 1 Petrus, komunitas 1 Petrus menjadi komunitas yang berani menantang dominasi kekaisaran Romawi dengan cara hidup serta cara pandang yang berbeda. Mereka digerakkan oleh ideologi household of God. Ideologi tersebut memimpin komunitas untuk hidup dalam semangat persaudaraan dan berada dalam jalan cinta. Ideologi tersebut memberi komunitas 1 Petrus identitas sebagai umat Allah dalam semangat persaudaran. Identitas tersebut melebur dalam identitas persaudaraan pada konteks masyarakat. Peleburan ini dapat terjadi karena ideologi household of God yang diperkenalkan oleh komunitas 1 Petrus diadaptasi dari sistem pemerintahan Roma yang disebut household of Caesar. Sistem tersebut juga diterapkan dalam keluarga sebagai unit dasar dalam masyarakat Romawi. ${ }^{104}$ Ideologi household of God menjadi terbuka karena bersumber dari masyarakat, ia tidak terbatas pada komunitas 1 Petrus.

Ammerman menyatakan bahwa kepedulian terhadap orang lain adalah tanggung jawab bersama, karena ia berkaitan dengan nilainilai keagamaan dan komunitas. Dalam bousebold semua orang merupakan saudara laki-laki dan saudara perempuan. Ikatan yang tidak hanya terbatas dalam kelompok tertentu, tetapi ikatan yang merangkul tetangga-tetangga, teman, mereka yang terasing, bahkan kelompokkelompok yang lain. ${ }^{105}$ Household berada dalam persinggungan antara yang privat dan publik, antara yang sakral dan profan. Persinggungan ini terjadi karena ia tidak hanya berfungsi dalam keluarga atau pun masyarakat, melainkan juga berfungsi dalam kehidupan spiritualitas. ${ }^{106}$

Pernyataan Ammerman menegaskan bahwa nilai-nilai dalam ideologi household of God berasal dan berfungsi pada masyarakat dan komunitas Kristen. Ideologi household of God memberi sumbangsih bagi

104 Elliott, A Home for the Homeless, 174-77.

105 Ammerman, Sacred Stories, Spiritual Tribes, 21.

106 Ibid., 20. 
identitas sosial Kristen yang terbuka, yakni identitas persaudaran. Identitas persaudaraan mengajak setiap orang untuk hadir bagi yang lain, suatu kehadiran yang memberdayakan.

Perempuan Timor Timur, komunitas 1 Petrus, dan kita adalah anggota dalam housebold of God. Narasi perempuan Timor Timur dan komunitas 1 Petrus mengingatkan kita tentang identitas persaudaraan, identitas yang berjuang untuk keadilan dengan jalan mencintai. Melalui identitas itu, setiap kita terkait satu sama lain. Kita terkait dengan para perempuan Timor Timur yang masih terpuruk karena peristiwa traumatis yang dialami, para pelaku kekerasan di Timor Timur yang belum mengakui kejahatan mereka, maupun orang-orang lain yang berada dalam penderitaan. Kita semua dipanggil untuk bekerja bersama-sama menciptakan dunia yang adil dan damai. Panggilan untuk berjuang demi keadilan pada jalan mencintai adalah panggilan bersama.

\section{Penutup}

Narasi para korban tidak hanya tinggal sebagai sejarah. Ia mampu menentang, menggugah kesadaran, merangkul pihak lain, dan menghadirkan suatu identitas sosial Kristen yang terbuka. Identitas tersebut adalah identitas persaudaraan, ideologi household of God.

Sejak penarikan tentara Indonesia dari Timor Timur, Timor Timur masih hidup dalam keadaan yang menderita sampai hari ini. Seakan-akan kemerdekaan Timor Timur dibayar oleh penderitaan yang belum berakhir. Saat ini, timor Timur sedang berjuang dengan infrastuktur yang masih tertinggal, ketimpangan sosial-ekonomi yang mendalam dan terus tumbuh, banyaknya pengangguran akibat sangat rendahnya tingkat perkembangan ekonomi di Timor Timur, pendidikan dan pelayanan kesehatan yang berkualitas buruk. ${ }^{107}$

Kelaparan adalah persoalan yang umum di Timor Timur. Kaum perempuan Timor Timur, khususnya korban kekerasan seksual dari tentara Indonesia pada tahun 1975-1999, masih merasa terjajah karena mereka masih hidup dalam kemiskinan. ${ }^{108}$

Poverty is widespread in East Timor with $41.5 \%$ of the population living below the poverty line of US $\$ 0.88$ cents per capita per day. What is more concerning is that this has increased by $2 \%$ in just three years. Life expectancy at birth is

107 Nevins, Pembantaian Timor Timur: Horor Masyarakat Internasional, 277.

108 Agniya Khoiri, "Potret Luka Perempuan Timor Leste Dalam

'Memoria'," CNN Indonesia 2016. 
60 years and more than half of the 1.1 million population are under 18 years of age. $58 \%$ of Timor-Leste children suffer from chronic malnutrition. It is a fact that $38 \%$ of children suffer from anemia most often caused by poor diet, malaria, diarrhea and intestinal worms. Health standards are extremely low and many people must walk up to four hours to reach the closest medical facility. Infant mortality rate is very high with 52 deaths from every 1000 live births. 20\% of children have no access to primary education and adult literacy levels are below $60 \%{ }^{109}$

Situasi Timor Timur mengajak semua pihak untuk tidak lupa dan bersama-sama berjuang sebagai bentuk pertanggungjawaban atas kekejaman di masa lalu serta turut terlibat bagi pembangunan Timor Timur. Ideologi household of God menjadi pengingat bahwa identitas persaudaraan adalah identitas kita dan identitas itu harus diterapkan dalam kehidupan bermasyarakat.

\section{Tentang Penulis}

Astrid Bonik Lusi adalah seorang pengajar di Fakultas Teologi Universitas Kristen Satya Wacana Salatiga, Jawa Tengah. Ia menyelesaikan pendidikan S1, Sarjana Sains Teologi, di Universitas Kristen Satya Wacana, 2012 dan pendidikan S2, Magister Teologi, di STTT Jakarta, 2015.

\section{Daftar Pustaka}

Ammerman, Nancy Atom. Sacred Stories, Spiritual Tribes: Finding Religion in Everyday Life. New York: Oxford University Press, 2014.

Ammerman, Nancy Tatom. Studying Congregations: A New Handbook. Nashville: Abingdon Press, 1998.

Asumang, Annang. "'Resist Him' (1 Peter 5:9): Holiness and Non-

Retaliatory Responses to Unjust Suffering as 'Holy War' in 1

Peter." Conspectus (South African Theological Seminary) 11, no. 1 (2011): 7-46.

Australian Timor-Leste Advancement Society (ATLAS). "The Current Situation in Timor-Leste." Australian Timor-Leste Advancement Society (ATLAS).

109 Australian Timor-Leste Advancement Society (ATLAS), "The Current Situation in Timor-Leste," Australian Timor-Leste Advancement Society (ATLAS). 
Bauman-Martin, Betsy J. "Women on the Edge: New Perspectives on Women in the Petrine Haustafel." Journal of Biblical Literature 123, no. 2 (2004): 253-79.

Campbell-Nelson, Karen, dkk. Perempuan Dibawa/ h Laki-Laki yang Kalab: Kekerasan terbadap Perempuan Timor Timur dalam Kamp Pengungsian di Timor Barat. Kupang: JKPIT \& PIKUL, 2001.

Comissão de Acolhimento Verdade e Reconciliação Timor Leste (CAVR). Chega! The Report of the Commission for Reception, Truth, and Reconciliation Timor-Leste Executive Summary. Timor Leste: Comissão de Acolhimento Verdade e Reconciliação Timor Leste (CAVR), 2005.

Ehrman, Bart D. The New Testament: A Historical Introduction to the Early Christian Writings. 2nd ed. New York: Oxford University Press, 2000.

Elliott, John Hall. A Home for the Homeless: A Sociological Exegesis of 1 Peter, Its Situation and Strategy. United States of America: Fortress Press, 1981.

Ganzevoort, R. Ruard. "Scars and Stigmata: Trauma, Identity, and Theology." Practical Theology 1, no. 1 (2008): 19-31.

Hakh, Samuel Benyamin. Perjanjian Baru: Sejarah, Pengantar, dan PokokPokok Teologisnya. Bandung: Bina Media Informasi, 2010.

Herman, Judith Lewis. Trauma and Recovery. New York: Basic Books, 1997.

Horrell, David G., Bradley Arnold, and Travis B. Williams. "Visuality, Vivid Description, and the Message of 1 Peter: The Significance of the Roaring Lion (1 Peter 5:8)." Journal of Biblical Literature 132, no. 3 (2013): 697-716.

Jenkins, Richard. Social Identity. 3rd ed. London; New York: Routledge, 2008.

Jones, Serene. Trauma and Grace: Theology in a Ruptured World. Louisville, Kentucky: Westminster John Knox Press, 2009.

Khoiri, Agniya "Potret Luka Perempuan Timor Leste Dalam 'Memoria'." CNN Indonesia, 2016.

Klinken, Helene van. Anak-Anak Tim-Tim di Indonesia: Sebuab Cermin Masa Kelam. Jakarta: KPG (Kepustakaan Populer Gramedia), 2014.

Marxsen, Willi. Pengantar Perjanjian Baru: Pendekatan Kritis terhadap Masalab-Masalahnya. Jakarta: BPK Gunung Mulia, 2012.

Montgomery, Robert L. Introduction to the Sociology of Missions. Westport, Conn.: Praeger, 1999.

Negara dan Kekerasan terhadap Perempuan. Kekerasan Negara Terhadap Perempuan Di Timor Timur. Edited by George J.

Aditjondro. Jakarta: Yayasan Jurnal Perempuan (YJP), 2000. 
Nevins, Joseph. Pembantaian Timor Timur: Horor Masyarakat Internasional. Yogyakarta: Galangpress, 2008.

Perrin, Norman, Dennis C. Duling, and Robert L. Ferm. The New Testament, an Introduction: Proclamation and Parenesis, Myth and History. 2nd ed. New York: Harcourt Brace Jovanovich, 1982.

Rimmer, Susan Harris. Gender and Transitional Justice: The Women of East Timor. Routledge Contemporary Southeast Asia Series. London; New York: Routledge, 2010.

Schnelle, Udo. The History and Theology of the New Testament Writings. Minneapolis, MN: Fortress Press, 1998.

Sedmak, Clemens. Doing Local Theology: A Guide for Artisans of a New Humanity. Faith and Cultures Series. Maryknoll, N.Y.: Orbis Books, 2002.

Tenney, Merrill C. New Testament Times. United States of America: Wm. B. Eerdmans Publishing Co., 1965.

Tedeschi, Richard G. and Lawrence G. Calhoun. Trauma and Transformation: Growing in the Aftermath of Suffering. Thousand Oaks, London, New Delhi: Sage Publications, 1995.

Van Rensburg, Fika Janse. "Constructing the Economic-Historic Context of 1 Peter: Exploring a Methodology." Hervormde Teologiese Studies 67, no. 1 (2011): 1-11.

Walsh, Pat. Di Tempat Kejadian Perkara: Tulisan, Refleksi, dan Puisi tentang Timor-Leste, 1999-2010. Jakarta: KPG (Kepustakaan Populer Gramedia), 2012.

Williams, Travis B. Persecution in 1 Peter: Differentiating and Contextualizing Early Christian Suffering. Leiden: Brill, 2012. 